\title{
An Experimental Study Of The Impact Of Shading On The Performance Of Various Solar Home System Photovoltaic Technologies
}

\author{
Ambrosius A. Tino, Julius Tanesab*, Muchamad Ali \\ \{ambrostino@yahoo.com, julius_halan@yahoo.co.id*, muchammadali123@gmail.com\} \\ ${ }^{1}$ Politeknik Negeri Kupang
}

\begin{abstract}
Performance of a photovoltaic (PV) module is influenced by the amount of solar irradiation received by its cells. One of the trigger factors of PV performance degradation is shading due to passing clouds and high objects surrounding the PV area. This study aimed to examine the impact of shading on the performance degradation of polycrystalline (pc-Si) and mono-crytalline (mc-Si) modules - common PV technologies installed on solar home systems in Nusa Tenggara Timur (NTT) province, Indonesia. The shading patterns were simulated to cover the modules horizontally and vertically. Experimental results showed that short circuit current (Isc) and open circuit voltage (Voc) generated by the two solar module technologies decreased proportionally with the increasing of shading levels. Compared to the Voc, Isc was the more affected parameter caused by shading. Furthermore, it was found that mc-Si was the technology that accounted more degradation than pc-Si.
\end{abstract}

Keywords: shading, PV performance, PV degradation, short circuit current

\section{Introduction}

The needs of electricity have become an inseparable part of all aspects of human life. Therefore, the generation of electric power should be sustainable and secure [1]. Based on the sources, electric power generation can be classified into renewable and non-renewable. Utilization of non-renewable energy sources shares negative impacts on the environment. Nonrenewable energy sources produce a large amount of nitrogen oxides, sulfur oxides and other suspended particles [2]. These compounds cause environmental pollution and harm effect on human health and other living things. Another disadvantage is that gas emitted also causes global warming. These negative effects have promoted a global demand for renewable energy sources that are environmentally friendly [1].

Solar, wind, hydro, geothermal, biomass, and wave energy are identified as renewable sources of energy. Among these sources, solar energy has been a source applied widely and grow very rapidly to produce electric power by applying a photovoltaic module [3]. The technology, which utilizes photon energy from the Sun, is considered to have characteristics of good reliability, easy to install, and no noise pollution. A photovoltaic module is constructed from a number of solar cells connected in series with voltage output of 0.5 volts each. In large PV systems, the modules are connected in series and parallel to obtain the desired current and voltage. 
In addition to the large-scale solar systems, PV panels are applied individually to provide electric power for small-scale loads in a house. The system is commonly known as a solar home systems (SHS). Performance of PV modules installed in the field is influenced by many factors including shading [4,5]. This phenomenon can be caused by high objects surrounding the SHS like buildings and trees and the passing clouds [6]. The incidence of shading blocks the sunlight that should be received by solar cells of the panel. As a result, current generated by the panel decreases leading to a decline of power output. The more the cells of the panel are blocked, the greater its performance decreased [7].

There have been many studies on the effects of shading on the performance degradation of PV modules. Kovach and Schmid [8] conducted a study to investigate loss of power output of PV modules caused by shading. A raytracing program was then developed and used to simulate solar lighting in buildings. They found that there was a decrease in power due to shading. The amount of energy loss was dependent on the configuration of the modules in the system. Kaushika and Ray [9] in their research revealed that when a module experienced shading, current and voltage outputs of other modules in an array declined as well. Karatepe et al. [10] in a study revealed that power output of a module decreased as much as $50 \%$ when it was exposed to a $5 \%$ of shading.

As an effort to reduce energy losses and permanent damage due to shading, solar panels are usually equipped with bypass diodes. The components are connected parallelly with a number of solar cells in the junction box of the module. Ideally, each cell must be connected with a bypass diode [11], but this, understandable, would trigger an increase in panel prices. In practice, the number of bypass diodes installed on each solar panel product varies. For example, a module that has 60 cells are connected with 3 bypass diodes, each bypass diode is installed parallelly with 20 cells. Meanwhile, modules featuring 72 cells are usually connected with 4 bypass diodes, but some products have 3 bypass diodes [12].

Nusa Tenggara Timur (NTT) is a province blessed with significant amount of sunlight total intensity of radiation is around $6.6 \mathrm{kWh} / \mathrm{m}^{2}$ per year $[13,14]$. The number is the highest compared to other provinces in Indonesia. Featuring an archipelago geographic, generating electricity using solar energy is the right choice for the province. At present the installed capacity of solar panels has reached almost $9 \mathrm{MW}$ where around $35 \%$ of the systems are classified as grid connected while more than $60 \%$ are off-grid systems. Most of the off-grid systems are solar home system [15].

Different PV technologies respond differently to the adverse effect caused by shading. Tripathi et al. [2] in a laboratory study compared the performance of mc-Si and pc-Si modules under shading conditions. The test results showed that mc-Si module has better performance than pc-Si. For example, at a shading strength of $25 \%$, power output of the modules decreased by $40.72 \%$ and $41.40 \%$ for $\mathrm{mc}-\mathrm{Si}$ and $\mathrm{pc}-\mathrm{Si}$, respectively.

Literature review shows that previous studies were focused on simulations of larger PV systems. This research, therefore, was dedicated to perform an experimental testing of the effect of shading on small solar panels. In line with its application for SHS in NTT, solar panels in the areas are also potential to experience shading. In contrast to the grid-connected system, energy losses in SHS even in a small value is very meaningful as the lost can be utilized to run small energy-efficient appliances $[13,16]$. This study went further by finding out what were the effects of shading on PV modules, especially on the pico-solar photovoltaic modules commonly used for SHS in NTT. The modules tested representing the SHS photovoltaic module technologies deployed in NTT, namely monocrystalline ( $\mathrm{mc}-\mathrm{Si})$ and polycrystalline (pc-Si) $[14,15]$. 


\section{Experimental methodology}

A laboratory experiment was performed to determine the impact of shading on the performance of solar modules. A solar simulator was deployed to investigate the degradation of electrical parameters of the modules. The equipment was built from 50 watts halogen lamps as shown in Figure 1. The solar simulator was covered to prevent others light intervention. The intensity of the lamps and temperature inside the simulator were set at a standard condition, $1000 \mathrm{~W} / \mathrm{m}^{2}$ and $25^{\circ} \mathrm{C}$, respectively. It was simulated that the modules experienced shading in certain patterns, namely horizontal and vertical. Solar cells' configuration and variation of shading patterns are shown in Figure 2. Two PV modules consisting of pc-si and mc-si commonly used in SHS in NTT were applied as samples of this experiment. The specifications of the modules are shown in Table 1. PV module performance is usually assessed based on its electrical parameters such as short circuiit current (Isc) and open circuit voltage (Voc). The value of the parameters under shading and without shading conditions were compared. Kyoritsu ammeter and voltmeter with an error tolerance of $3 \%$ was applied to measure current and voltage of the modules. Meanwhile, the intensity of light of solar simulator was measured with a SM206 Solar solar power meter. Electrical test circuit is shown in Figure 3.

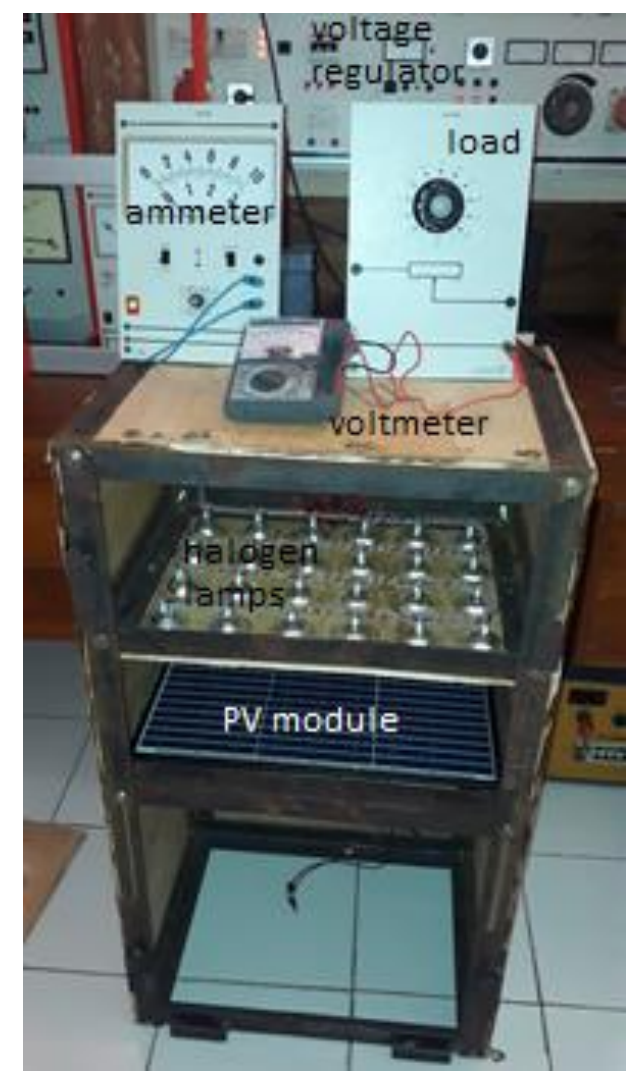

Figure 1. Halogen-based solar simulator 
Table 1. Technical specification of the examined solar panels

\begin{tabular}{lrr}
\hline Parameters & $\mathrm{mc}-\mathrm{Si}$ & $\mathrm{pc}-\mathrm{Si}$ \\
\hline Maximum power (Pmax) & $10 \mathrm{~W}$ & $10 \mathrm{~W}$ \\
Voltage @ Pmax (Vmp) & $17.83 \mathrm{~V}$ & $17.40 \mathrm{~V}$ \\
Current @ Pmax (Imp) & $0.56 \mathrm{~A}$ & $0.58 \mathrm{~A}$ \\
Short circuit current & $0.61 \mathrm{~A}$ & $0.63 \mathrm{~A}$ \\
Open circuit voltage & $21.75 \mathrm{~V}$ & $21.70 \mathrm{~V}$ \\
\hline
\end{tabular}
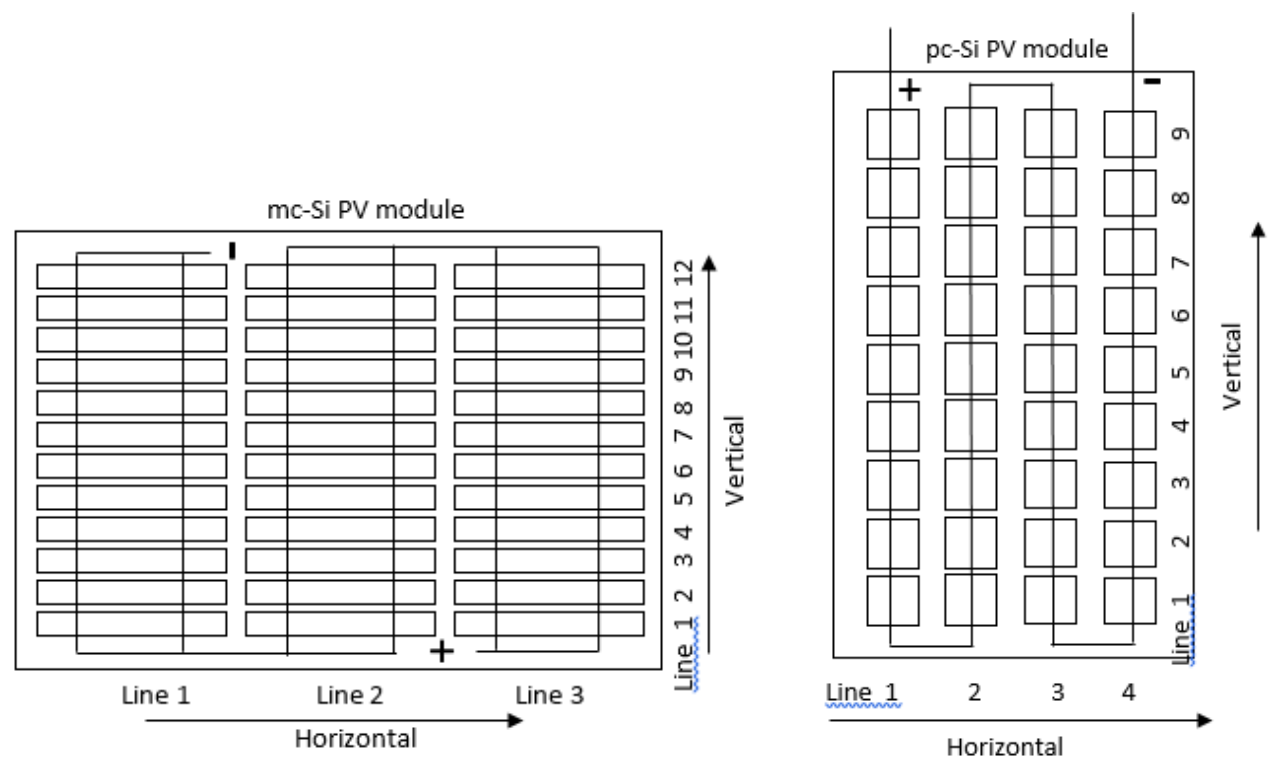

Figure 2. Solar cells' configuration and shadding patterns

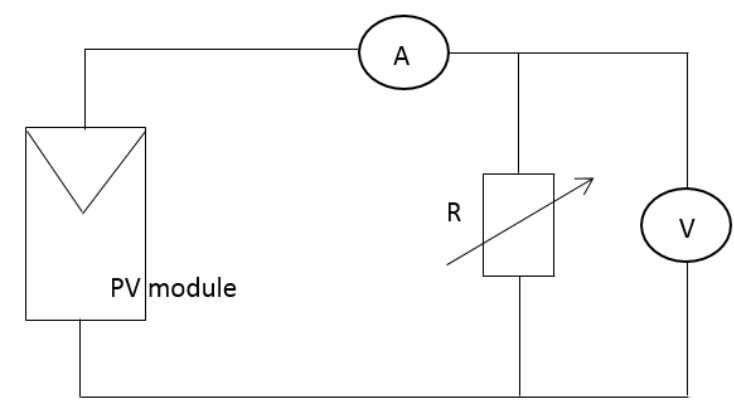

Figure 3. Electrical circuit diagram for the measurement of Isc and Voc 


\section{$3 \quad$ Results and discussion}

Measurement results of short circuit current (Isc) and open circuit voltage (Voc) of mc-Si module without shading at intensity of $1000 \mathrm{~W} / \mathrm{m}^{2}$ and temperature of $25^{\circ} \mathrm{C}$ are $0.3 \mathrm{~A}, 18.02$ $\mathrm{V}$, and $10 \mathrm{~W}$, respectively. Meanwhile, for the pc-Si module, it was obtained $0.25 \mathrm{~A}, 18.05 \mathrm{~V}$, and $10 \mathrm{~W}$. Furthermore, the results of the electrical parameters of the PV modules under shading conditions as explained in the methodology section are shown in Table 2 and Table 3.

Table 2. Reduction values of PV modules' parameters under horizontal shadings

\begin{tabular}{lllll}
\hline \multirow{2}{*}{ Shading patterns } & \multicolumn{3}{c}{ mc-Si } & \multicolumn{2}{c}{ pc-Si } \\
\cline { 2 - 5 } & $\begin{array}{l}\text { Reduction } \\
\text { in Isc }(\%)\end{array}$ & $\begin{array}{l}\text { Reduction } \\
\text { in Voc }(\%)\end{array}$ & $\begin{array}{l}\text { Reduction } \\
\text { in Isc }(\%)\end{array}$ & $\begin{array}{l}\text { Reduction } \\
\text { in Voc }(\%)\end{array}$ \\
\hline Line 1 & 85.4 & 2.10 & 82.40 & 1.84 \\
Lines 1,2 & 86.6 & 3.44 & 89.20 & 4.83 \\
Lines 1,2,3 & 91.6 & 12.87 & 92.80 & 7.28 \\
Line 1,2,3,4 & 95.0 & 15.09 & 95.20 & 10.92 \\
Lines 1 to 5 & 95.3 & 16.65 & 96.00 & 14.94 \\
Lines 1 to 6 & 98.6 & 18.42 & 96.80 & 19.56 \\
Lines 1 to 7 & 99.0 & 22.86 & 97.20 & 22.82 \\
Lines 1 to 8 & 99.16 & 30.07 & 97.60 & 23.36 \\
Lines 1 to 9 & 99.33 & 34.51 & N/A & N/A \\
Lines 1 to 10 & 99.56 & 37.40 & N/A & N/A \\
Lines 1 to 11 & 99.50 & 42.06 & N/A & N/A \\
\hline
\end{tabular}

Note: N/A: not applicable

Table 3. Reduction values of PV modules' parameters under vertical shadings

\begin{tabular}{lllll}
\hline \multirow{2}{*}{$\begin{array}{l}\text { Shading } \\
\text { pattern }\end{array}$} & $\begin{array}{l}\text { Reduction } \\
\text { in Isc (\%) }\end{array}$ & $\begin{array}{l}\text { Reduction } \\
\text { in Voc }(\%)\end{array}$ & $\begin{array}{l}\text { Reduction } \\
\text { in Isc }(\%)\end{array}$ & $\begin{array}{l}\text { Reduction } \\
\text { in Voc }(\%)\end{array}$ \\
\hline Line 1 & 100 & 10.09 & 88.40 & 1.30 \\
Lines 1,2 & 100 & 26.74 & 93.20 & 8.80 \\
Lines $1,2,3$ & N/A & N/A & 95.20 & 16.03 \\
\hline
\end{tabular}

Note: N/A: not applicable

Experimental results show that all shading patterns cause a serious degradation on the performance of the PV modules. Short circuit current (Isc) is the most affected parameter due to shading. Voc values vary slightly only from $2 \%$ to $23 \%$ for both modules under all shading conditions, while Isc decreased significantly between $85 \%$ and $100 \%$. These results are in line with previous works conducted by $[2,4,6-8]$ who claimed that Isc decreases proportionally with the declining of solar intensity.

Based on technology, mc-Si accounted better performance than pc-Si when both technologies were subjected to the shadings' condition. For example, when cells of the modules were shaded vertically (Line 1), Isc of mc-Si did not produce any current (Isc $=0)$, while Isc of 
pc-Si decreased from 0.25 A to 0.029 A $(88.40 \%)$. The more series of the cells were shaded, the more the Isc degraded.

It is interesting to note that when both modules were shaded horizontally, pc-Si still yielded smaller Isc values than the mc-Si one. This shows that the pc-Si material is able to work better in shading conditions compared to mc-Si. These results confirm the results of a study of Tanesab et al [4] who found that pc-Si works better in dust shading even though it was not statistically significant. According to Ferrada et al. [17], mc-Si technology shows better performance than pc-Si in high temperature conditions. This study has provided a valuable information to the SHS owners in NTT to pay more attention to the conditions around their PV systems. Even small amount of power losses is very meaningful for PV applications, especially for small systems like SHS as the energy can be used to run small energy-efficient appliances.

\section{Conclusion}

Shading caused degradation on the performance of PV modules. The experiment results show that short circuit current (Isc) is the more affected parameter compared to the open circuit voltage (Voc). Decreasing values of Isc and Voc of mc-Si technology under all shading patterns were greater than pc-Si technology. Based on the degradation pattern, horizontal shadings reduce the performance of both modules more significantly than the vertical ones. On the same pattern, pc-Si gives better performance compared to mc-Si module. It is recommended that the owner of PV systems especially SHS should pay more attention to the conditions around their modules to avoid shadings as the losses can be used to run small energy-efficient appliances.

\section{Acknowledgements}

The authors would like to thank Politeknik Negeri Kupang for the financial support through the RUTIN Research programme. A thank you also goes to Gratia and Abraham for their help to record the values of electrical parameters of the modules using the halogen solar simulator.

\section{References}

[1] IEA: PVPS Trends 2016 in Photovoltaic Applications. Retrieved August 20, 2018, from http://iea-pvps.org/index.php?id=256 (2016).

[2] Tripathi, A. K. and C. S. N. Murthy: Effect of shading on PV panel technology. 2017 International Conference on Energy, Communication, Data Analytics and Soft Computing (ICECDS), Chennai. pp. 2075-2078 (2017).

[3] IEA: Renewables in global energy supply: an IEA fact sheet (2006).

[4] Tanesab, J., Parlevliet, D., Whale, J., Urmee, T., \& Pryor, T.: The contribution of dust to performance degradation of PV modules in a temperate climate zone. Solar Energy, 120, 147 -

157. doi: http://dx.doi.org/10.1016/j.solener.2015.06.052 (2015). 
[5] Tanesab, J., Markus, D. L., Ambrosius, A. T., \& Yohanes, S. P.: Experimental study of dust impact on power output degradation of various photovoltaic technologies deployed in West Timor, Indonesia. IOP Conference Series: Earth and Environmental Science, 188(1), 012038 (2018).

[6] Deline, C.: Partially shaded operation of multi-string photovoltaic systems. In 2010 35th IEEE Photovoltaic Specialists Conference (2010).

[7] Hanitsch, R., D. Schulz, and U. Siegfried: Shading effects on output power of grid connected photovoltaic generator systems. Rev. Energ. Ren.: Power Engineering, p. 93-99 (2001)

[8] Kovach A, Schmid J.: Determination of energy output loss due to shading of buildingintegrated photovoltaic arrays using a raytracing technique. Sol Energy;57(2):117-24 (1996)

[9] Kaushika N, Rai A. An investigation of mismatch losses in solar photovoltaic cell networks. Energy 2007;32:755-9 (2007)

[10] Karatepe E et al.: Voltage based compensation system for PV generation system under partially shaded insolation conditions. Energy Convers Manage 2008;49(8):2307-16 (2008)

[11] Lu, F., et al., Improved PV module performance under partial shading conditions. Energy Procedia, 33: p. 248-255 (2013)

[12] Woyte, A., J. Nijs, and R. Belmans: Partial shadowing of photovoltaic arrays with different system configurations: literature review and field test results. Solar energy, 74(3): p. 217-233 (2003)

[13] Tanesab, J., Parlevliet, D., Whale, J., \& Urmee, T.: Dust Effect and its Economic Analysis on PV Modules Deployed in a Temperate Climate Zone. Energy Procedia, 100, 65-68. doi: https://doi.org/10.1016/j.egypro.2016.10.154 (2016).

[14] Tanesab, J., Parlevliet, D., Whale, J., \& Urmee, T.: Seasonal effect of dust on the degradation of PV modules performance deployed in different climate areas. Renewable Energy, 111, 105-115. doi: https://doi.org/10.1016/j.renene.2017.03.091 (2017).

[15] Retnanestri, M., \& Outhred, H.: Outcomes of an ADRA Research Project to Overcome Barriers to Renewable Energy in Rural Indonesia by Community Capacity Building. Solar 2011, the 49th AuSES Annual Conference (2011).

[16] Tanesab, J., Parlevliet, D., Whale, J., \& Urmee, T.: Energy and economic losses caused by dust on residential photovoltaic (PV) systems deployed in different climate areas. Renewable Energy 120 401-12 (2018).

[17] Ferrada, P., Araya, F., Marzo, A., \& Fuentealba, E.: Performance analysis of photovoltaic systems of two different technologies in a coastal desert climate zone of Chile. Solar Energy, 114, 356-363. doi: http://dx.doi.org/10.1016/j.solener.2015.02.009 (2015). 